\title{
Plant-Based Milks: Coconut ${ }^{1}$
}

\section{Celia Andreo, Daniela Rivero-Mendoza, and Wendy J Dahl²}

Coconut milk is one of the many varieties of plant-based alternatives to cow's milk. Factors that may steer consumers toward non-dairy milk alternatives include adherence to a vegan diet, lactose intolerance, allergy to cow's milk, or simply preference (Sethi et al. 2016). The purpose of this guide is to provide information on the nutrient content of coconut milk and its potential health benefits and risks.

\section{How is coconut milk made?}

Coconut milk contains water and coconut cream-a concentrated form of coconut milk. This publication focuses on diluted coconut milk sold as a beverage as opposed to the more concentrated, often canned coconut milk intended as a cooking ingredient. Other ingredients added to coconut milk may include lecithin, for emulsification, and gums for thickening and texture (Patil et al. 2018, USDA n.d.). Also, salt may be added for taste. Some brands of coconut milk are fortified with calcium and vitamins $\mathrm{A}$ and $\mathrm{D}$ to provide levels of these nutrients similar to cow's milk (USDA n.d.). Vitamin B12 may be added to provide a source of this nutrient for individuals consuming a vegan diet.

Coconut cream is made from dry-pressing coconut meat. The coconut cream is then diluted with water to make a coconut milk beverage. Coconut milk may also be made by soaking grated mature coconut meat in water. Heat processing is used to ensure the product is shelf stable (Patil et al. 2018). Note that coconut milk is quite different from coconut water. Coconut water is a sweet, translucent fluid that can be consumed directly from the coconut or as commercially packaged varieties.

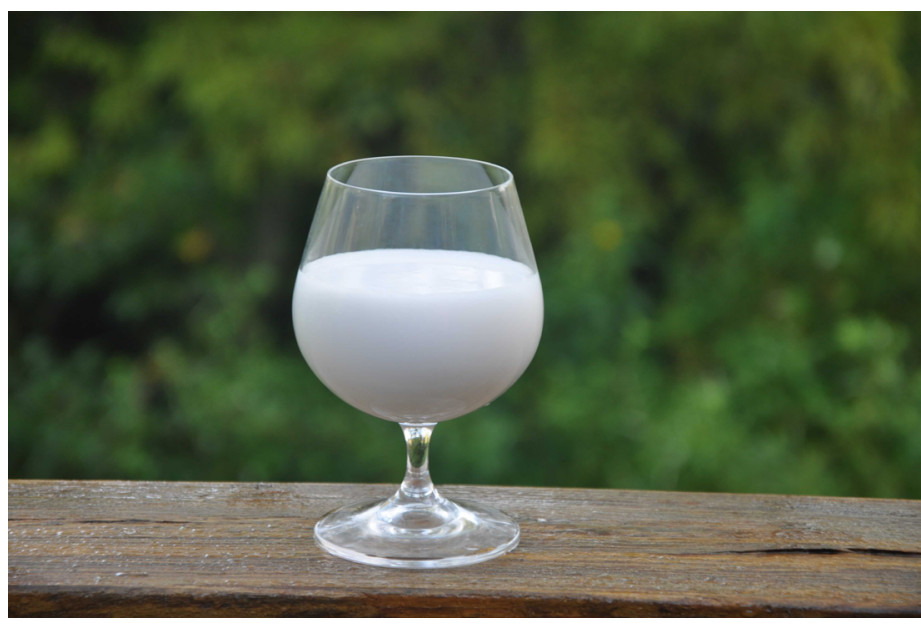

Credits: Lincoln Zotarelli, UF/IFAS

\section{How does the nutrient profile of coconut milk compare to cow's milk?}

An important point to consider when selecting a plantbased milk is the nutritional composition. The nutritional content of coconut milk is different from that of cow's milk. Table 1 shows a comparison between unsweetened coconut milk and fat-free, low-fat, and whole cow's milk (USDA n.d.).

Calories. One cup of unsweetened coconut milk contains 40 calories, which is less than any type of cow's milk (USDA n.d.). Note that the calorie content of unsweetened coconut milk intended as a beverage is much lower than the coconut milk, often canned, intended for cooking. Canned coconut

1. This document is FSHN20-49, one of a series of the Food Science and Human Nutrition Department, UF/IFAS Extension. Original publication date October 2020. Visit the EDIS website at https://edis.ifas.ufl.edu for the currently supported version of this publication.

2. Celia Andreo, former MS-DI graduate student, Food Science and Human Nutrition Department; Daniela Rivero-Mendoza, Extension and research coordinator; and Wendy J Dahl, associate professor, Food Science and Human Nutrition Department; UF/IFAS Extension, Gainesville, FL 32611.

The Institute of Food and Agricultural Sciences (IFAS) is an Equal Opportunity Institution authorized to provide research, educational information and other services

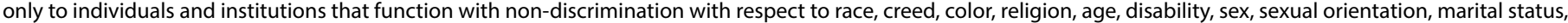

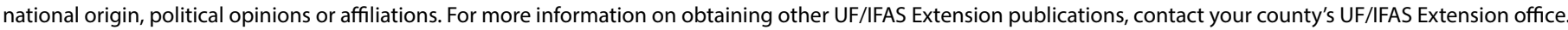
U.S. Department of Agriculture, UF/IFAS Extension Service, University of Florida, IFAS, Florida A \& M University Cooperative Extension Program, and Boards of County Commissioners Cooperating. Nick T. Place, dean for UF/IFAS Extension. 
milk or cream, which is much more concentrated, may contain up to 400 calories per cup (USDA n.d.).

Protein. Cow's milk is a significant source of protein, whereas coconut milk provides no protein (USDA n.d).

Fat. The fat content of unsweetened coconut milk is lower than that of whole cow's milk but is higher than fat-free or low-fat cow's milk. The fat in coconut milk is mainly saturated fat, a higher percentage than in whole and low-fat cow's milks (USDA n.d.).

Carbohydrate. Cow's milk contains about $12 \mathrm{~g}$ of carbohydrates per serving, almost all of which is in the form of lactose, a sugar that is naturally present in milk (USDA n.d.). Unsweetened coconut milk contains only $1 \mathrm{~g}$ of carbohydrate (Silk n.d.-b). However, flavored varieties of coconut milk may contain as much as $15 \mathrm{~g}$ of carbohydrate per serving, a significant portion of which are added sugars (USDA n.d., Silk n.d.-a). The US Dietary Guidelines discourage the consumption of added sugars, including sugar-sweetened beverages (USDA 2015). Coconut milk is not a source of fiber.

Vitamins and Minerals. Both cow's milk and coconut milk are fortified with vitamins $A$ and $D$, although levels may be higher in coconut milk (Silk n.d.-b). Coconut milk is also fortified with calcium at a level higher than cow's milk. Coconut milk may be fortified with vitamin B12 at a level similar to cow's milk. Coconut milk is typically lower in sodium than cow's milk, but sodium levels may vary depending on the manufacturer.

\section{What are the potential health benefits of coconut milk?}

It is important to consider your dietary needs before switching to coconut milk. One potential benefit of unsweetened coconut milk is the low caloric content. An individual who is monitoring their caloric intake for weight-loss purposes may select unsweetened coconut milk because it provides fewer calories than cow's milk. However, consumers should be aware of the type of coconut milk they buy. Some varieties of coconut milk may include significant amounts of added sugars and thus may provide more calories than cow's milk. Cow's milk is an important source of protein as well as many other nutrients, compared to coconut milk, which provides no protein. This is an important consideration, especially for children and adolescents who are growing, and for older adults who have higher protein needs (Bauer et al. 2015).
Coconut milk, like other plant-based milks, does not contain lactose, making it suitable for people with lactose intolerance. However, if lactose intolerance is the only concern, lactose-free cow's milk is also available on the market.

Coconut is not considered a major food allergen by the US Food and Drug Administration (FDA), whereas dairy is first on the list (FDA n.d.). Individuals with an allergy to cow's milk protein can safely consume coconut milk. Coconut milk has a similar advantage over other plantbased milks, which contain major allergens (e.g., soy and almond). Coconut milk is also suitable for inclusion in a vegan or ovo-vegetarian diet.

\section{What are the possible risks of consuming coconut milk?}

There may be disadvantages to consuming coconut milk. For example, it has a high saturated fat content compared to other plant-based milks. In the Dietary Guidelines for Americans, it is recommended to consume less than 10 percent of calories per day from saturated fats to reduce the risk for cardiovascular disease (USDA 2015). Opting for a plant-based milk with lower fat content, such as almond, oat, rice, or cashew milk, or choosing fat-free cow's milk may be a better option for limiting saturated fat intake.

\section{Is coconut milk an appropriate choice for children?}

For optimum growth and development, children must consume enough calcium, vitamin $\mathrm{D}$, and protein. Cow's milk is a source of all three nutrients, which is why cow's milk helps build strong bones and teeth. Much like other plant-based milks, coconut milk is fortified with calcium. This added form of calcium may not be absorbed by our bodies as easily as naturally occurring calcium (Bridges 2018, Singhal et al. 2017). For children who are between the ages of 1-8 years, one serving of fortified coconut milk ( 1 cup) provides roughly $50 \%$ of the calcium and $25 \%$ of the vitamin D they need to consume in one day, similar to cow's milk (Vitoria 2017). However, cow's milk can provide a significant portion of a child's daily protein needs (Vitoria 2017), whereas coconut milk provides none (Silk n.d.-b, Vitoria 2017). Coconut milk, like other plant-based milks, should never be fed to infants. Older children should not drink coconut milk exclusively. If plant-based milks are being considered as a beverage for children, parents and caregivers should consult their health care provider for guidance with supplementing protein, vitamins, and calories elsewhere in the diet (Vitoria 2017). 


\section{Summary}

Coconut milk is a plant-based alternative fortified with vitamins and calcium but is a source of saturated fat. Unsweetened coconut milk is a low-calorie beverage. Because it lacks protein, coconut milk should not replace cow's milk in the diets of children.

\section{References}

Bauer, Juergen M., and Rebecca Diekmann. 2015. "Protein and Older Persons." Clinics in Geriatric Medicine 31 (3): 327-338. https://doi.org/10.1016/j.cger.2015.04.002.

Bridges, Meagan. 2018. "Moo-Ove over, Cow's Milk: The Rise of Plant-Based Dairy Alternatives." Practical Gastroenterology 21. https://practicalgastro.com/wp-content/ uploads/2019/07/Moo-ove-Over-Cow-Milk-Rise-of-PlantBased-Dairy-Alternatives.pdf. [Accessed 10th August 2020].

Patil, Umesh, and Soottawat Benjakul. 2018. "Coconut Milk and Coconut Oil: Their Manufacture Associated with Protein Functionality." Journal of Food Science 83 (8): 2019-2027. https://doi.org/10.1111/1750-3841.14223.

Sethi, Swati, S. K. Tyagi, and Rahul K. Anurag. 2016. "Plant-Based Milk Alternatives an Emerging Segment of Functional Beverages: A Review." Journal of Food Science and Technology 53 (9): 3408-3423. https://doi.org/10.1007/ s13197-016-2328-3.

Silk. n.d.-a. "Original Coconutmilk." https://silk.com/ plant-based-products/coconutmilk/original-coconutmilk/. [Accessed 10th August 2020].

Silk. n.d.-b. "Unsweet Coconutmilk." https://silk.com/ plant-based-products/coconutmilk/unsweet-coconutmilk/. [Accessed 10th August 2020].

Singhal, Sarita, Robert D. Baker, and Susan S. Baker. 2017. "A Comparison of the Nutritional Value of Cow's Milk and Nondairy Beverages." Journal of Pediatric Gastroenterology and Nutrition 64 (5): 799-805. https://doi.org/10.1097/ mpg.0000000000001380.

United States Department of Agriculture (USDA). 2015. "Dietary Guidelines for Americans 2015-2020." http:// health.gov/dietaryguidelines/2015/guidelines/. [Accessed 10th August 2020].
United States Department of Agriculture (USDA). n.d. "FoodData Central." https://fdc.nal.usda.gov/index.html. [Accessed 10th August 2020].

U.S. Food and Drug Administration (FDA). n.d. "Food Allergies: What You Need to Know." https://www.fda. gov/Food/ResourcesForYou/Consumers/ucm079311.htm. [Accessed 10th August 2020].

Vitoria, Isidro. 2017. “The Nutritional Limitations of PlantBased Beverages in Infancy and Childhood." Nutrición Hospitalaria 34 (5): 1205-1214. https://www.redalyc.org/ pdf/3092/309253341026.pdf. [Accessed 10th August 2020]. 
Table 1. Nutrient profile of unsweetened coconut milk compared to fat-free, low-fat, and whole cow's milk.

\begin{tabular}{|c|c|c|c|c|}
\hline & $\begin{array}{l}\text { Unsweetened coconut milk } \\
\text { ( } 1 \text { cup) }\end{array}$ & $\begin{array}{l}\text { Fat-free skim milk } \\
\text { ( } 1 \text { cup) }\end{array}$ & $\begin{array}{l}\text { Low-fat ( } 1 \%) \text { milk } \\
\text { ( } 1 \text { cup) }\end{array}$ & $\begin{array}{l}\text { Whole milk } \\
\text { ( } 1 \text { cup) }\end{array}$ \\
\hline Energy (Calories) & 40 & 83 & 102 & 150 \\
\hline Protein (g) & 0 & 8 & 8 & 8 \\
\hline Total fat (g) & 4 & 0 & 2.4 & 8 \\
\hline Saturated fat (g) & 3 & 0.1 & 1.5 & 4.5 \\
\hline Carbohydrate (g) & 1 & 12 & 12 & 12 \\
\hline Fiber (g) & 0 & 0 & 0 & 0 \\
\hline Total sugars (g) & 0 & 12 & 12 & 12 \\
\hline Vitamin A (mcg) & 180 & 149 & 142 & 112 \\
\hline Vitamin B12 (mcg) & 0.9 & 1 & 1 & 1 \\
\hline Vitamin D (mcg) & 2 & 3 & 3 & 3 \\
\hline Calcium (mg) & 460 & 298 & 305 & 276 \\
\hline Sodium (mg) & 45 & 102 & 107 & 105 \\
\hline Potassium (mg) & 310 & 381 & 366 & 322 \\
\hline
\end{tabular}

